\title{
KONSELING PEREMPUAN
}

\author{
Ulfiah \\ Fakultas Psikologi UIN Sunan Gunung Djati Bandung, Jl. A.H Nasution No. 105 Bandung \\ email: ulfiahmdc@yahoo.co.id
}

\begin{abstract}
Abstrak
Perempuan mempunyai status yang sama dengan laki-laki. Tidak ada perbedaan antara laki-laki dan perempuan berkenaan dengan status, hak-hak, dan balasan, baik di dunia maupun akhirat kelak. Keduanya adalah individu yang setara dalam pelaksanaan fungsifungsi kehidupan sehari-hari. Sepanjang sejarah Islam, perempuan telah memainkan peran yang sangat penting. Dengan prestasi mereka, perempuan telah memperlihatkan betapa luasnya wilayah yang diberikan Islam kepada mereka untuk melaksanakan amal mulia dan heroik, dan juga menunjukkan betapa mulianya posisi perempuan dalam masyarakat Islam. Dengan perkembangan global yang terjadi sekarang ini, maka peran laki maupun perempuan cenderung mengalami perubahan dan perkembangan yang begitu pesat. Kecenderungan perubahan peran perempuan tersebut terjadi karena adanya peluang yang semakin terbuka. Fenomena ini sungguh dapat memberikan perluang perempuan untuk mengaktualisasikan potensinya, akan tetapi kesempatan ini bisa menjadi masalah jika pemahaman akan peran gender ini tidak dipahami secara menyeluruh. Oleh karena itu konseling dibutuhkan untuk memberikan pemahan bagaimana perempuan mampu mengaktualisasikan potensinya secara optimal
\end{abstract}

Kata kunci: konseling dan perempuan

Abstract

Women have the same status as the man. There is no differences of status and human right between women and men. Both men and women have the same function in the social life. In the long history, women had the important role. With their achievement, Islam has given the large area to the women in doing good action and heroic. Islam has shown a good position for the women in social life. In the global area, the role of women and men had changed. Women tends to get the public role. The tendencies of women change is because of the opened opportunities for the women. This Phenomenon gives the opportunities to the women to express their potential. But it will be a problem if the women don't understand the role of gender totally. So, counseling has to give the right understanding in expressing their potential.

Key word: counseling and women

\section{PENDAHULUAN}

Allah "menciptakan pasangan laki-laki dan perempuan dari jiwa yang sama" semata-mata berarti bahwa perempuan berasal dari spesies yang sama dengan laki-laki. Allah telah menciptakan mereka seperti itu supaya ada keharmonisan antara kedua jenis kelamin. Jika laki - laki dan perempuan berasal dari spesies yang berlainan, misalnya, yang satu diciptakan dari api, dan yang satunya lagi dari tanah, maka keduanya tidak akan bisa disatukan. Kehidupan keluarga tidak akan memiliki ketentraman dan keharmonisan: Laki-laki dan perempuan tidak akan dapat berjuang bahu- membahu untuk membangun dunia yang lebih baik. 
Berkenaan dengan sabda Nabi yang mempersamakan perempuan dengan tulang rusuk, ini adalah suatu ibarat yang melukiskan keharusan untuk memperlakukan perempuan secara lemah lembut karena sifat khusus dan pembawaan mereka. Nabi Muhammad menyampaikan nasihat ini berkali-kali, dengan ungkapan yang berbeda, dan ini adalah sikap yang beliau praktekkan sepanjang hidupnya.

Isu gender sekarang ini kadang seolaholah menunjukkan ketidakpuasan alias protes terhadap realitas yang dihadapi, semestinya hal ini perlu direnungi bersama bagaimana mengkaji persoalan perempuan diawali dengan kajian agama sehingga akar masalahnya jelas dan tidak saling tuding atau bahkan demi kepentingan politik tertentu yang pada gilirannya dapat mengurangi perbedaan pandangan tentang perempuan itu sendiri bahkan peran gendernya.

Tulisan ini diharapkan mampu memberkan pemahaman tentang persoalan perempuan dengan uraian beberapa kasus dan fenomena lain yang berkaitan dengan budaya Negara tertentu yang ada dalam isi bab ini, peran gendernya bahkan implementasi pada konseling dalam mengatasi masalah perempuan dimaksud.

\section{Fenomena Perempuan}

Walaupun populasi wanita mencapai $51 \%$ di U.S, dalam hal ini perempuan sering mengalami perlakuan diskriminasi dan stereotipe. Beberapa perkembangan telah diperjuangkan untuk kesetaraan jender, tetapi ketidakadilan terus berlangsung, koalisi nasional pelajar perempuan mempublikasikan laporan yang mengindikasikan bahwa (a) Wanita terus berada di bawah dalam banyak bidang seperti halnya matematika dan sains; (b) Wanita mendapat upah yang rendah, wanita berada pada jejak wanita tradisional; (c) Wanita terdiri dari 73\% guru SD dan SMP tetapi hanya 35\% yang menjadi kepala sekolah; (d) Adanya perbedaan antara pendidik pria dan wanita bertahan pada semua level; (e) Pelajar perempuan kurang mendapat perhatian, dorongan, dan pujian dibanding dengan pelajar pria; dan (f) Pelecehan seksual terhadap pelajar perempuan terus terjadi. Studi mengindikasikan bahwa $81 \%$ dari kelas $8-11,30 \%$ siswa yang belum lulus dan $40 \%$ siswa yang telah lulus mengalami pelecehan seksual. Situasi yang sering memberikan pengaruh negatif terhadap ketertarikan untuk bersekolah. Guru sering tidak peduli/ sadar bahwa mereka mungkin mempromosikan paham seks (sexism) dengan memberikan respon-respon yang berbeda kepada pelajar laki-laki dan perempuan. Berikut contoh ketidakadilan seorang guru kelas tiga terhadap muridnya (a) Akomodasi pujian diberikan kepada siswa laki-laki untuk menghentikan perdebatan dari pada menghadapi mereka; (b) Siswa laki-laki diizinkan untuk berbicara secara bergiliran sedangkan siswa perempuan tidak; dan (c) Ketika siswa perempuan mendapatkan giliran berbicara mereka harus mengangkat tangan mereka terlebih dahulu (Garrahy, 2001).

Maksud dalam wilayah pendidikan, keprofesionalitasan kesehatan mental perlu dilibatkan dalam menganjurkan level perubahan yang melibatkan kurikulum dan susunan kepegawaian. Tugas guru selanjutnya adalah memasukkan demonstrasi dan diskusi dari responrespon yang menyampaikan pesan-pesan yang membatasi gender. Tingkah laku benar-benar mempengaruhi penampilan. R.P Brown dan Josephs (1999) menyatakan bahwa gender mempengaruhi penampilan. Stereotipe bahwa seseorang jelek dalam sesuatu hal akan mempengaruhi penampilan. Tingkah laku dan pengharapan yang berkenaan dengan karakteristik kepribadian stereotipe dan pilihan karir tertentu perlu ditujukan dalam program-program pendidikan, dalam komunitas akademik, dokumentasi tertentu telah dibuat untuk meningkatkan kesuksesan staf pengajar perempuan (APA Public Interes, 2001) adalah (1) Menjunjung keadilan dalam berpartisipasi, kompensasai, penugasan, dan sumber-sumber, (2) Mengajukan perempuan sebagai pemimpin, (3) Pastikan garis komunikasi antara staf pengajar perempuan dan bagian administrasi (4) Memberikan kesempatan kepada perempuan untuk studi lanjut, (5) Menyuport lembaga bantuan seperti kelompok staf guru perempuan dan komite perempuan, (6) Mendorong menyemangati administrator yang tidak akan mentoleransi rasisme dan sexisme, (7) Menyuport/ membantu pelajar-pelajar yang berhubungan dengan psikologi perempuan dan masalahmasalah gender, (8) Meminta kebijakan luas menolak sexisme atau pelecehan seksual (9) Meminta kesadaran institusi dan suportif terhadap permasalahan-permasalahan gender yang dapat mempengaruhi guru dan siswa dalam proses pendidikan. 


\section{Permasalahan yang Dihadapi Perempuan}

\section{Status ekonomi}

$40 \%$ keluarga yang dikepalai oleh seorang perempuan saja hidup dalam kemiskinan, dengan penghasilan dibawah 12.500 dolar pertahun (Kantrowitz \& Wingertt, 2001). Dalam pendapatan, perempuan mendapatkan lebih sedikit penghasilan dari pada laki-laki; perbedaan ini sering dinyatakan antara perempuan kulit putih dan laki-laki kulit putih, dengan perempuan mendapatkan kurang dari $3 / 4$ gaji yang diterima oleh laki-laki (U.S Bureau of the Sensus, 1995). Karir-karir bukan tradisional sering tidak bersahabat dengan perempuan, perempuan mempunyai banyak kesempatan untuk pekerjaan-pekerjaan seperti: sekretaris $(98,5 \%)$, kasir $(78,3 \%)$, perawat $(89,4 \%)$, guru SD $(83,9 \%)$ dan resepsionis $(96,5 \%)$ dan mereka sulit untuk bekerja di posisi administrasi (U.S Department of Labor, 1998). Walaupun dalam pekerjaan-pekerjaan dimana perempuan berada pada angka mayoritas, mereka menerima gaji lebih sedikit dari pada laki-laki dalam pekerjaan yang sama (Atkinson \& Hackett, 1998). Banyak perempuan berada dalam masalah-masalah kesehatan mental, lebih dari $50 \%$ laporan menyatakan kekerasan domestik dan mengalami gejala stres (PTSD; Women's Program Office, 1998).

Perempuan yang berada dalam kemiskinan memerlukan pertolongan dari masalahmasalah ekonominya, penginapan, dan pangan. Keprofesionalan kesehatan mental mungkin perlu untuk menggunakan kemampuan manajemen permasalahan untuk mendapatkan sumber-sumber bagi klient Karena pertimbangan finansial layanan kesehatan mental harus diberikan seperti klinik perencanaan keluarga (konseling pra nikah), layanan kepedulian kesehatan (Klinik Kesehatan Reproduksi), dan kantor urusan pemerintah. Kepedulian anak dan program-program lain bagi anggota keluarga seperti ibu yang menerima konseling dapat meningkatkan partisipasi dalam sistem kesehatan mental.

\section{Hambatan pilihan karir}

Sarjana perempuan merasa lebih tertekan untuk pilihan karir mereka jika dibandingkan dengan laki-laki. Mayoritas sarjana perempuan merasakan adanya rintangan yang lebih tinggi terhadap karir mereka karena permasalahan-permasalahan latar belakang etnik dan jender (Luzzo \& MC Whirter, 2001). Kurangnya jumlah wanita dalam lapangan-lapangan kerja tertentu karena adanya stereotipe peranan jender. Beberapa pekerjaan membutuhkan karakteristik yang tidak seperti perempuan. Kefeminiman termasuk kualitas emosional, kesensitifan, pemeliharaan, dan saling ketergantungan (E.P. Cook, 1990). Jika perempuan bertindak dengan cara yang tidak dianggap feminism, konsekuensi negatif akan muncul kepada mereka. Jika perempuan memperlihatkan tugas yang berorientasi pada kepemimpinan yang melanggar norma kesopanan jender, dia dipandang seperti seseorang yang kompeten tetapi mereka akan bernilai rendah dalam daya tarik sosial, tetapi tidak untuk lakilaki. Mereka dipandang lebih kompeten dan lebih disukai (Rudman, 1998).

Pebisnis perempuan melaporkan kesulitan kenaikan pangkat pada tingkatan hukum (Lyness \& Thompson, 2000). Ini diwujudkan seperti (1) Mereka dibuat merasa dihargai, tidak cocok dengan level senior. Mereka merasa tidak nyaman dengan laki-laki yang bekerja dengan mereka, yang tidak mempunyai model peranan gender yang sama dan merasa bahwa mereka harus tampil pada level yang lebih tinggi dari pada perempuan, (2) Perempuan mendapatkan mentoring yang kurang efektif dari pada laki-laki. Beberapa masalah dibatasi oleh akses mentor yang potensial, (3) Karena pandangan stereotipe, perempuan mendapatkan kesulitan untuk mendapatkan tugas-tugas yang diperlukan untuk kenaikan pangkat dalam karir mereka dan (4) Laki-laki menambah batasan-batasan budaya dengan menekan persahabatan dan perbedaan dari perempuan, merahasiakan informasi yang penting untuk pekerjaan kepada mereka. Jaringan kerja informal lebih berguna untuk menejer laki-laki dibandingkan yang menejer perempuan.

Pengaruh pada karir sedikit berbeda dengan perempuan Amerika keturunan Afrika yang menghadapi permasalahan-permasalahan rasisme \& sexisme. Nilai yang penting berkenaan dengan kesuksesan karir adalah promosi pendidikan oleh keluarga, hubungan yang baik dengan anggota keluarga, sosialisasi jender keluarga dan nilai-nilai akan pekerjaan.

Keprofesionalan kesehatan mental akan membantu pilihan karir untuk perempuan. Dalam melakukan hal yang sama, pendekatan 
komprehensif harus ada di dalamnya. Satu program (Sullivan \& Mahalik, 2000) Meningkatkan karir pribadi perempuan lulusan perguruan tinggi dengan meminta mereka untuk mengidentifikasi pencapaian karir yang sukses, berpartisipasi dalam pembelajaran melalui observasi ini dicapai dengan menginterview perempuan diluar kelompok mengenai proses pembuatan keputusan karir mereka, mendiskusikan observasi tentang pandangan mengenai keputusan karir mereka dan membaca materi-materi tentang perkembangan karir perempuan yang unik, menghadiri acara penggerakan emosi dan pembelajaran untuk mengatur kegelisahan melaui relaksasi dan pembicaraan pribadi yang adaptif. Perempuan belajar mengidentifikasi dan merubah pemikiranpemikiran yang mengalahkan dirinya sendiri serta mengalami semangat yang menggelora dan godaan secara lisan.

Kesuksesan karir senantiasa ditingkatkan oleh kelompok perempuan seperti mengembangkan evaluasi kemampuan diri, mengidentifikasi garis karir dengan perempuan sukses, mempromosikan kemampuan untuk menghadapi kegelisahan dan membantu mereka memahami pengaruh permasalahan sosialisasi jender dalam karir perempuan.

\section{Diskriminasi dan pengorbanan perempuan}

Kira-kira $20 \%$ pelajar perempuan melaporkan telah mengalami pelecehan seksual atau fisik oleh partner kencan mereka. Pelecehan ini diasosiasikan dengan meningkatnya penggunaan narkoba, minum-minuman, dan percobaan bunuh diri, kerusakan pola makan, berhubungan seksual sebelum umur 15 tahun (Silverman, Raj, Mucci, dan Hathway, 2001). Jelas bahwa korban pelecehan ini sering menderita depresi dan kesulitan-kesulitan emosional lainnya. Mayoritas perempuan yang sedang menjalani pengobatan akibat pelecehan seksual usia dini menderita PTSD (Rodriguez, Ryan, Vande Kemp, dan Foy, 1997). Pelecehan seksual juga umum terjadi dalam lingkungan pekerjaan.

Umumnya kekerasan seksual pada perempuan terjadi dan ini berdampak pada masalah kesehatan mental. Kantor kebijakan APA (2001) merekomendasikan inisiatif-inisiatif kebijakan, termasuk perbaikan legal dan legislatif yang menunjukan permasalahan kekerasan terhadap perempuan; meningkatkan training kesehatan mental pekerja untuk mengobati korban dan menghargainya; penyebaran informasi atas kekerasan terhadap wanita ke gereja dan kelompok komunitas, institusi pendidikan, dan masyarakat umum dan eksplorasi terhadap intervensi sosiokultural dan psikoedukasional untuk merubah keobjektifan lelaki terhadap perempuan.

\section{Masalah Gender}

Gender berasal dari bahasa latin, yaitu "genus", berarti tipe atau jenis. Gender adalah sifat dan perilaku yang dilekatkan pada laki-laki dan perempuan yang di bentuk secara sosial maupun budaya. Karena di bentuk oleh sosial dan budaya setempat, maka gender tidak berlaku selamanya tergantung kepada waktu dan tempatnya. Hal ini sesuai dengan pernyataan Stemberg (1993) bahwa istilah gender menggambarkan pada konsepsi-konsepsi mengenai peran jenis kelamin yang ditentukan secara sosial.

Sebagai suatu konsepsi gender yang mengacu pada pengertian bahwa seorang dilahirkan sebagai laki-laki atau perempuan keberadaannya berbeda-beda dalam waktu, tempat, kultur, bangsa maupun peradaban, dimana keadaan itu berubah-ubah dari masa kemasa.

Gender berkaitan dengan proses keyakinan bagaimana seharusnya laki-laki dan perempuan diharapkan untuk berfikir dan bertindak sesuai dengan ketentuan sosial dan budaya dimana mereka berada, jadi perbedaan tersebut ditentukan oleh aturan masyarakat dan bukan karena perbedaan biologis.

Peranan gender adalah peranan sosial yang ditentukan oleh perbedaan kelamin, misalnya mengasuh anak dan mengurus rumah tangga digolongkan sebagai peranan dan tanggung jawab perempuan, sedangkan mencari nafkah dan memenuhi kebutuhan rumah tangga adalah peran dan tanggung jawab lakilaki. Ini harus dipahami bahwa tugas tersebut adalah sebagai peranan gender terhadap lakilaki dan perempuan, bukan peranan kodrat laki-laki atau perempuan. Dengan kata lain, peranan ini tidak menjadi sebuah kemutlakan, akan tetapi jika kondisi yang tidak memungkinkan atau dengan kesepakatan kedua belah pihak, peran tersebut bisa di tukar atau digantikan. Sangat berbeda sekali dengan peranan kodrat perempuan yang tidak dapat digantikan yakni haidh, hamil dan menyusui. 
Oleh karena itu, peranan gender menjadi aspek dasar yang perlu mendapat perhatian bagi setiap individu, karena masalah jenis kelamin ini telah menimbulkan stereotype gender yang sangat fariatif. Stereotype gender yang di maksud adalah anggapan tentang apa arti menjadi perempuan atau laki-laki, termasuk hal-hal yang berkenaan dengan penampilan, sikap dan kepentingan sifat-sifat psikologis, hubungan sosial, dan pekerjaan. Terhadap gender perempuan timbul berbagai dimensi yang saling berkaitan dengan mengetahui bahwa ia seorang perempuan, juga menyatakan bahwa orang tersebut memiliki sifat tertentu (suara lembut, anggun dsb) dan sifat-sifat psikologis tertentu(kewanitaan), dan melakukan kegiatan tertentu(mengurus anak, memasak, mencuci pakaian dsb)

Standar stereotipe kecantikan yang diungkapkan melalui iklan dan media masa mempunyai pengaruh terhadap kesehatan dan penghargaan diri perempuan. Tekanan sosial bagi perempuan untuk menjadi kurus telah menimbulkan internasionalisasi bentuk tubuh yang tidak realistik seperti ideal dan menghasilkan ketidakpuasan terhadap bentuk tubuh dan kerusakan pola makan dan diet (Stice, Shaw, dan Nemsoff, 1998). Diperkirakan 35\% wanita mengadakan diet dan mencoba mengontrol berat badan mereka dengan memaksakan diri menahan nafsu lapar dan menggunakan obat pencahar kebutuhan untuk memenuhi standar kecantikan atau kerampingan menjadi lebih kuat ketika gadis-gadis pada usia 12 dan 13 mulai kencan dan mengalami perubahan penampilan fisik dan kebanyakan dari mereka memulai untuk melakukan diet (Heatherton, Mahamedi, Striepe, Field, dan Keel, 1997).

Program-program perlu menujukan pengaruh tekanan masyarakat atas kerampingan seperti standar dimana perempuan harus menilai diri mereka sendiri. Beberapa program telah dikembangkan untuk mengembangkan internasionalisasi imej (kesan) tubuh paling ramping. Dikepemimpinan YMCA, mereka mengadakan program penyelesaian masalah dengan olah raga, dan berpartisipasi dalam komunikasi dan diskusi. Kemp itu berhasil membantu partisipant untuk menyadari bahwa mereka mempunyai reaksi yang sama terhadap tekanan masyarakat dan belajar mengembangkan standar internal yang mereka bisa merasa baik dengan keadaannya (Stein Berg, 1998).
Dalam konseling individu, Sands (1998) menyatakan dalam bekerja dengan perempuan yang rusak pola makannya: pertama, kenalkan mereka untuk mengidentifikasi konteks sosial dan budaya untuk kebiasaan sehingga mereka tidak menyalahkan diri mereka sendiri. Analisis peranan jender mengikuti fikasi pesan bahwa mereka menerima dari mayarakat (perempuan harus ramping, cantik dan seksi). Kedua, tentukan konsekuensi pesan hubungan jender dan pernyataan diri mereka yang diasosiasikan dengan mereka. Ketiga, pilih pesan yang cocok (sehat itu penting, jadi saya akan makan dan olah raga dengan cukup), dan mengembangkan rencana untuk mengimplementasikan perubahan.

Tujuh juta perempuan mengalami depresi akhir-akhir ini dan ini dua kali terjadi pada laki-laki (Schwartzman dan Glans, 2000). Nilai yang sama ditemukan antara perempuan Amerika keturunan Afrika dan laki-lakinya. Bagaimanapun juga tidak ada pemisah perbedaan jender yang jelas bagi ketidakberhasilan telah ditemukan untuk orang Amerika Hispanik (Robins dan Regier, 1991). Faktor-faktor yang mengakibatkan depresi pada perempuan termasuk status ekonomi yang miskin, standar jender masyarakat yang tidak sehat dan stres akibat trauma (Culbertson, 1997). Perempuan merasa tekanan memenuhi stereotipe peranan sosial yang feminism dimana mereka diuji menurut kecantikan fisik, sopan santun, dan kesiapan menikah. Penyimpangan dari standarstandar ini dapat menimbulkan keraguan pada diri sendiri perasaan diri yang miskin, dan depresi (Sands, 1998). E.p. Cook (1990) percaya bahwa depresi berasal dari pensosialisasian mereka untuk mencoba mendapatkan hubungan dengan harga sesuai dengan kebutuhan mereka sendiri. Kegagalan dalam hubungan sering dilihat sebagai kegagalan pribadi, yang menggabungkan stres dan mempengaruhi rasa.

Hampir 20\% wanita mengalami aborsi. Mereka melaporkan gejala depresi yang lebih besar dan kepuasan hidup yang lebih rendah dari pada kelompok perempuan lainnya. Dalam studi Russo dan Denious (2001) menemukan bahwa aborsi tidak ada hubungannya dengan kesehatan mental yang tidak baik. Ini adalah pelecehan seksual, kekerasan pasangan, dan pemerkosaan yang dihubungkan dengan ide bunuh diri, depresi dan kegelisahan. 
Penilaian terhadap faktor-faktor lingkungan seperti rasisme, kemiskinan, kondisi ekonomi, dan hubungan yang kurang baik mengidentifikasi pengaruh yang mungkin dari seksisme (sexisme) atau pesan jender individu yang menjadi baik. Beberapa orang percaya bahwa depresi adalah versi ekstrim peran perempuan yang ditentukan masyarakat (kepasifan, Penghargaan diri yang rendah, bergantung pada yang lain, Sands, 1998). Selama masa remaja intensifikasi jender menjadi lebih kuat dan ada peningkatan tekanan masyarakat untuk menjadi cantik, popular dan feminism. Penyimpangan dari standar ini menghasilkan isolasi dari yang lain dan penolakan kelompok. Mengidentifikasi kesadaran berdasarkan stereotipe dan mengembangkan penguasaan pernyataan diri yang lebih realistik dapat mengurangi depresi.

Depresi pada wanita diasosiasikan meningkatnya resiko penyakit cardiovascular, yang mengakibatkan kematian pada wanita. Dengan konsekuen, kesehatan mental yang professional harus mendidik perempuan mengenai resiko dan kemungkinan berkembangnya penyakit jantung koroner (CHD). Resiko kesehatan lainnya seperti merokok, diet yang berlebiahn, gaya hidup yang menetap, dan obesitas, intervensi psikologi harus digunakan untuk memodifikasi ini semua. Seorang perempuan juga harus tahu gejala CHD (penat, pusing, pingsan, rasa sakit di dada, atau berkeringat, atau rasa sakit yang menyebar ke leher, rahang lengan, atau punggung; Schwartzman dan Glaus, 2000).

\section{Usia}

Dengan tekanan pada anak muda dan seksisme di masyarakat kita, wanita yang lebih tua dipandang negatif dari pada lelaki tua. Beberapa perempuan percaya bahwa diskriminasi umur ditunjukkan oleh orang-orang yang lebih muda yang tidak berhubungan dengan mereka secara sosial; dengan pilihan yang diberikan kepada perempuan yang lebih muda di toko-toko, restoran, dan tempat-tempat umum lainnya; dengan mengurangi kesempatan kencan dan dengan tidak bertemu dengan laki-laki (Committee on Woman In Psychology, 1999). Ada beberapa imej positif dari perempuan tua. Perempuan tua menghadapi stres tambahan pada sindrom "emty nest" dan monopause (Lippert, 1997). Kira-kira 50 juta wanita yang berusia lebih dari 45 mengalami monopause.
Respon terhadap hal ini mungkin dipengaruhi oleh ageism dan sexism. Beberapa orang mungkin percaya bahwa ketertarikan seksual dan anak muda hilang pada saat monopause. Perempuan yang lebih muda mengalami tingkah laku yang lebih negatif untuk menuju masa monopause dibandingkan perempuan yang telah mengalami monopause (Huffman dan Myers, 1999). Beberapa wanita yang mengalami monopause, mereka merasa senang karena mereka mendapatkan kebebasan, bebas dari rasa kekhawatiran mengenai apa yang orang lain pikirkan, bebas dari tugas sebagai orang tua, dan kemampuan untuk mendefinisikan identitas mereka berdasarkan ketertarikan mereka sendiri (MC Quide, 1998).

Ahli kesehatan mental yang professional harus hati-hati untuk tidak membuat asumsi tentang apa yang disebut krisis pertengahan hidup dalam diri perempuan dan bagaimana masa transisi mempengaruhi klien. Perempuan mungkin perlu sadar akan perasaan yang kontradiksi yang mungkin diasosiasikan dengan bermacam-macam masa transisi pertengahan hidup seperti kehilangan perasaan simultan, dan rasa kebebasan ketika anak-anak meninggalkan rumah. Reaksi dan arti pribadi terhadap kejadian ini harus dipahami. Hilangnya peranan support dengan menegaskan komitmen baru dalam hidup. Menilai arti perkembangan pribadi melalui penjelajahan terhadap diri sendiri. Membantu mereka bahwa kegelisahan diharapkan berjalan melalui masa transisi dan ini adalah kesempatan untuk meraih perkembangan pribadi yang lebih baik bagi perempuan yang depresi setelah menopause, diskusikan pengaruh dari tingkah laku sosiokultural terhadap perempuan dan umur. Tentukan apa ketakutan mereka dan pengharapan-pengharapan dari proses itu. Berikan informasi terhadap proses dan adanya support kelompok.

\section{Teori Identitas Feminist}

Ahli terapi perempuan (feminism) percaya bahwa aspek patriarkhat masyarakat U.S bertanggung jawab atas banyaknya masalah yang dihadapi perempaun. Mereka percaya bahwa wanita menunjukkan macam reaksi kepada status yang lebih rendah dalam masyarakat. Tingkatan selanjutnya melambangkan evolusi kesadaran penaklukan perempuan dan perkembangan identitas feminism (MC Namara \& Rickard, 1998). 
Penerimaan pasif. Selama tingkatan ini, perempuan menerima peranan gender secara tradidional, melihat peranan-peranan itu seperti berguna bagi dia, dan menganggap lelaki lebih superior dari perempuan. Dia tidak sadar atau menyangkal diskriminasi. Kontribusi laki-laki terhadap seni, bisnis, dan teater dinilai lebih dominan dibandingkan perempuan.

Revolusi. Kejadian yang melibatkan sexism muncul dalam cara yang tidak dapat dihindari atau dilanggar. individu membangkitkan prasangka secara pribadi menjadi kemarahan dan merasa bersalah atas ketidaksadaran sebelumnya. Ada peningkatan ujian pribadi dan pemikiran yang dikotomi. Semua lelaki terlihat seperti menindas dan semua perempuan seperti pasif.

Kebermulaan dalam kedekatan. Perempuan mulai membentuk hubungan emosional yang lebih dekat dengan perempuan lainnya dengan bantuan mereka dia dapat mengungkapkan emosi mereka dalam lingkungan yang suportif. Identitas perempuan menjadi solid, dan dia berbicara lebih relatif dari pada pemikiran dualistik laki-laki.

Sintesis. Selama tingkatan ini, identitas feminist yang positif dikembangkan secara penuh. Sexism tidak lagi dianggap penyebab permasalahan sosial dan pribadi, dan faktor penyebab lainnya dipertimbangkan. Perempuan bisa mengambil pendirian yang berbeda dari perempuan feminism lainnya dan masih mendapatkan identitas kefemininannya. Komitmen yang aktif. Perempuan sekarang tertarik dalam merubah perhatiannya untuk membuat perubahan dalam masyarakat.

Walaupun beberapa perempuan berjalan melalui tingkatan ini, ini tidak jelas bagaimana model ini dapat diaplikasikan kepada kebanyakan perempuan. Teori berdasarkan pada pandangan W.E Cross 1971 mengenai perkembangan identitas orang Amerika keturunan Afrika. Cross merevisi model ini (W.e Cross, 1995), terutama ketika hal ini menggunakan tingkatan penerimaan pasif (preencounter). Individu pada tingkatan ini mungkin merasa bahwa karakteristik gender (ras) tidak lebih penting dari pada hal lain seperti agama, gaya hidup, dan status sosial. Mereka mungkin melihat kemajuan karena usaha pribadi/motivasi. Banyak individu pada tingkatan ini yang mempunyai tingkah laku ini sehat secara mental.

\section{Terapi Bagi Perempuan}

Ahli terapi perempuan mempunyai instrument dalam menunjuk sifat dasar masyarakat kita, walaupun dalam proses konseling. Penting bagi konselor untuk sadar akan permasalahan-permasalahan yang mungkin muncul dalam bekerja dengan klien perempuan. Kualitas seperti kepatuhan dalam bersikap dan lebih emosional dan hubungan yang diorientasikan dilihat sebagai kualitas positif dalam perempuan (Atkison \& Hackett, 1998). Jika konselor setia pada standar ini, secara sadar/ tidak sadar, tingkah laku ini mungkin disampaikan kepada klien dalam sesi konseling. Satu studi sesi terapi keluarga menyatakan bahwa konselor menyela perempuan lebih sering terjadi dari pada mereka menyela lakilaki (Werner-Wilson, Price, Zimmerman,\& Murphy, 1997). Walaupun therapist tidak sadar akan tingkah laku ini, mereka secara halus menyampaikan pengharapan peranan jender kepada keluarga.

Permasalahan-permasalahan dapat muncul karena kategori diagnostik tertentu. Beberapa kesalahan kepribadian mungkin didasarkan pada melebih-lebihkan karakteristik gender. Dramatisasi diri sendiri dan hubungan interpersonal, dan kepercayaan pada yang lain, ketidakmampuan memikul tanggung jawab adalah aspek semi drama, garis batas, dan kesalahan kepribadian yang bergantung kepada orang lain, bersifat respektif. Perempuan mungkin didiagnosa dengan kesalahan ini yang termasuk dalam Diagnostic and Statistical Mannual of Mental Disorders-Fourth Edition, Tex Reviosion (DSM-IV-TR). Ciri-ciri yang termasuk adanya perubahan nilai rasa, kemarahan, depresi, atau kegelisahan dibarengi dengan sakit pada tubuh yang mempengaruhi pekerjaan/aktivitas sosial. Kritik terhadap kategori ini menyatakan bahwa banyak wanita yang mempunyai gejala diatas tetapi menentang bahwa gejala-gejala itu harus diterima sebagai reaksi fisik. Menandai gejala-gejala sebelum menstruasi seperti kelainan psikologis mengembangkan pandangan bahwa perempuan itu emosional dan dikendalikan oleh hormon "raging" (hormon pengendali kemarahan). (D. Sue, Sue \& Sue, 1997).

Banyak teori kita diorientasikan kepada lelaki. Granello dan Beamish (1998) menyatakan bahwa konsep codependency perlu dikonsep ulang karena banyak perempuan akan 
menerima label ini. Codependency pada perempuan mungkin merefleksikan rasa keterhubungan, pemeliharaan, peranan penempatan kebutuhan keluarga di atas diri mereka sendiri. Tiga masalah muncul dalam konsep ini dalam model sistem keluarga. Pertama, tidak adanya pengakuan distribusi yang tidak seimbang dari kekuatan dalam keluarga. Tingkah laku codependent mungkin menghasilkan kekuatan yang tidak seimbang diantara laki-laki dan perempuan. Kedua, beberapa kunci konsep seperti perbedaan diri dan kegelisahan yang disebabkan peleburan emosi pada karakteristik stereotipe laki-laki. Ketiga, gangguan selalu diinterpretasikan pada sistem daripada anggota individu. Dibawah skenario ini perempuan yang disalah gunakan dapat dilihat sebagai kontributor permasalahan. Keempat, hubungan permasalahan dapat diinterpretasikan bukan satu-satunya permasalahan yang datang dari perempuan tetapi agaknya sebagai ketidakmampuan atau ketidakinginan laki-laki untuk berempati. Jadi, dalam banyak kasus, keinginan perempuan untuk keterhubungan adalah bukan sebuah penyakit tetapi sebuah kekuatan yang merupakan bagian penting dari konsep dirinya sendiri.

\section{Implikasi Konseling}

Baik konselor laki-laki / perempuan seyogyanya hati-hati untuk tidak membantu perkembangan peranan sex tradisional dan harus sadar akan asumsi sex. Munculnya permasalahan-permasalahan perlu dipahami dalam konteks kemasyarakatan dimana dievaluasi perempuan adalah sebuah kemunculan yang umum, konseptualisasi gender perlu dipertimbangkan sebagai aspek integral dalam konseling dan kesehatan mental. Baik itu peranan gender tradisional atau non tradisional memiliki keterkaitan. Setiap klien perempuan harus memilih apa yang terbaik untuknya menurut konsepsi gender atau kebenaran politik (Good, Gilbert, \& Scher, 1990).

Seperti yang Devoe (1998) katakan, kedua pendekatan konseling bukan sex dan kefemininan secara khusus dapat berguna dalam bekerja dengan perempuan yang tidak puas dengan reaksi peranan gender dan tertarik dalam mempengaruhi perubahan masyarakat. Bagaimanapun juga pandangan kefimininam tidak harus dipaksa pada klien yang percaya bahwa permasalahannya tidak berkaitan de- ngan gender. Konseling Nonsexist menggabungkan kekurangna filosofi feminist tetapi mencoba mengurangi pengaruh sexism ketika mengadakan konseling perempuan. Fitzgerald dan Nutt (1948) mengidentifikasikan beberapa petunjuk bagi konselor-konselor yang memberikan konseling pada perempuan. Petunjukpetunjuk ini mengidentifikasikan kepentingan penggabungan segi komponen-komponen $f e-$ minist dan Nonsexist dalam semua program konseling:

Memiliki informasi terkini yang berhubungan dengan masalah-masalah biologi, psikologi, dan sosiologi yang mempengaruhi perempuan. Contoh: pengetahuan mengenai menstruasi, kehamilan, kelahiran dll. Memperkenalkan teori konseling yang dipusatkan pada laki-laki dan membutuhkan modifikasi ketika bekerja dengan perempuan. Seperti pendekatan kognitif yang dapat memfokuskan pesan kemasyarakatan.

Menghadiri workshop untuk menjelajahi faktor-faktor yang berhubungan dengan jender dalam kesehatan mental dan berusaha untuk mengetahui masalah-masalah yang berhubungan dengan perempuan. Mempertahankan kesadaran semua tindakan dan memahami bagaimana itu berinteraksi dengan sexism.

Menggunakan kemampuan yang mungkin cocok untuk kebutuhan perempuan, seperti training ketegasan, analisis gender ketika menggunakan pendekatan dimana terjadi penolakan terhadap perspektif tradisional, klien perlu memahami konsekuensi pada perubahan. Menilai faktor-faktor sosiokultural un-tuk menentukan peranan mereka dalam menyampaikan masalah.

Menilai tingkah laku sexism yang penuh kebajikan, dimana perempuan dilihat sebagai mahluk yang harus dilindungi, disuport dan dipuji, dan yang menghasilkan tingkah laku yang menuntut mereka menjadi lemah dan pasif. Tingkah laku ini sering digunakan untuk membenarkan ketidaksetaraan gender dan merupakan bentuk halus dari sexism (Glick \& Fiske, 2001).

Membantu klien menyadari pengaruh pengharapan gender dan definisi kemasyarakatan dari ketertarikan terhadap kesehatan mental perempuan sehingga mereka tidak menyalahkan diri mereka.

Mempersiapkan klien untuk belajar mengenai sexism, hubungan dan karir. Siap untuk mengambil peranan pembelaan dalam 
mengajukan perubahan tingkatan sistem seperti yang mereka hubungkan dengan pendidikan, sexism, bisnis, dan usaha keras.

Menilai pengaruh yang mungkin dari penyalahgunaan/kekerasan terhadap perempuan. Menahan diri dari mengungkapkan tingkah laku konseling yang membatasi tujuan hidup atau karir perempuan. Menentukan ketika konselor perempuan adalah tandingan yang paling cocok bagi klien perempuan. Contoh, konselor laki-laki harus sadar ketika klien perempuan dilayani dengan layanan terbaik oleh konselor perempuan (masalah kahamilan, kekerasan domestik dan perkosaan).

\section{Status Perempuan dalam Islam}

Menurut Islam, perempuan mempunyai status yang sama dengan laki-laki. Dalam bahasa Al-qur'an"sebagian kalian adalah turunan dari sebagian yang lain"'(Q.S. annisa ayat 19). Tidak ada perbedaan antara laki-laki dan perempuan berkenaan dengan status, hakhak, dan balasan, baik di dunia maupun akhirat kelak. Keduanya adalah individu yang setara dalam pelaksanaan fungsi-fungsi kehidupan sehari-hari. Jika Islam menekankan pembagian kerja antara laki-laki dan perempuan ketimbang persamaan jenis kelamin, hal ini disebabkan Islam tidak menyetujui gagasan menderitanya salah satu jenis kelamin akibat perasaan direndahkan dan lebih inferior yang ditimbulkan oleh upaya meniru-niru jenis kelamin yang berbeda. Seperti yang pernah dikatakan oleh Nabi, "Laki-laki yang dikutuk adalah mereka yang berusaha menyerupai perempuan, dan perempuan yang dikutuk adalah mereka yang berusaha menyerupai laki-laki”.

Pembagian manusia secara biologis men-jadi laki-laki dan perempuan adalah akibat dari rencana sang Pencipta yang mempunyai maksud tertentu. Manusia tidak akan bisa maju jika mereka lalai mengindahkan pembagian ini. Setiap upaya untuk melanggar garis pembagian yang ditetapkan oleh yang Maha besar ini saja dengan melanggar seluruh sistem alam, satu jalan yang hanya akan menimbulkan kehancuran.

Laki-laki dan perempuan dalam Islam bukanlah duplikat satu sama lainnya, melainkan pelengkap, sebab pada masing-masing pihak ada perbedaan biologis mutlak yang mengakibatkan pemisahan lingkungan dan pekerjaan secra alami. Pembagian kerja ini memungkinkan kelemahan satu pihak ditutupi oleh kekuatan pihak lain. Ajaran Islam untuk laki-laki dan perempuan didasarkan pada sifat fitrah masing-masing. Sekarang sudah menjadi fakta biologis yang tidak bisa dipungkiri bahwa ada perbedaan didalam struktur fisiologis mereka, suatu perbedaan yang membuat laki-laki lebih cocok untuk bekerja diluar rumah. Perbedaan biologis ini tidak saja menjadi faktor penentu dalam pembagian kerja di masyarakat, tetapi juga mengharuskan disusunnya hukum Islam untuk menjamin keadilan bagi kedua jenis kelamin

Sepanjang sejarah Islam, perempuan telah memainkan peran yang sangat penting. Dengan prestasi mereka, perempuan telah memperlihatkan betapa luasnya wilayah yang diberikan Islam kepada mereka untuk melaksanakan amal mulia dan heroik, dan juga menunjukkan betapa mulianya posisi perempuan dalam masyarakat Islam.

Di dalam dunia Islam, Aisyah, putri Abu bakar dan istri Nabi, dikenal sebagai perempuan yang sangat cerdas, yang bakat intelektualnya dimanfaatkan di jalan Islam. Dibandingkan dengan Nabi, Aisyah masih sangat muda. Dia hidup hampir setengah abad lebih lama dari pada nabi. Didalam kurun waktu itu, dia menjadi sumber ajaran agama yang luar biasa otentik bagi umat. Hal ini sebagian besar disebabkan oleh keakuratan pidato-pidato, percakapan, dan perkataan Nabi yang tersimpan dalam ingatannya. Secara keseluruhan, Aisyah telah meriwayatkan kira-kira 2210 hadis Nabi, dan dengan bakat yang luar biasa, mampu merumuskan hukum dari hadis-hadis yang dikatakan bahwa tidak kurang dari seperempat keputusan syariat berasal dari hadis-hadis yang diriwayatkannya. Pengetahuan dan pemahamannya yang mendalam mengenai permasalahan agama begitu kukuh sehingga kapan saja para sahabat Nabi berbeda pendapat dalam setiap persoalan agama, mereka akan mendatanginya untuk mencari bantuan. Menurut Abu Musa al-Asy'ari, ketika para sahabat bimbang tentang makna suatu bagian dari suatu hadis, mereka akan pergi ke Aisyah. Jarang Aisyah tidak bisa memecahkan masalah mereka (AtTirmidzi, shahih, Abwab al-Manaqib dalam Wahiduddin Khan, 2001:188).

Walaupun Encyclopaedia Britannica (1984) menyebutkannya sebagai Aisyah, istri ketiga dari Nabi Muhammad, yang memainkan peran penting politis setelah wafatnya Nabi, 
tetapi arti penting sebenarnya dari Aisyah bukanlah mengenai keunggulan dirinya dalam sejarah Islam. Arti pentingnya adalah karena kedudukannya yang mampu menunjukkan adanya status tinggi bagi perempuan dalam Islam, dan juga karena betapa luas bidang yang bisa dijadikan ajang pemanfaatan kemampuan perempuan. Karena ciri khas Islamlah, makanya dia dapat memberikan pengabdian sosial dan politik yang sedemikian berarti. Selanjutnya banyak juga dikisahkan beberapa perempuan yang menjadi andalan dalam perjuangan Islam seperti Maryam dan Khadijah, yang menjadi suri tauladan bagi para perempuan / bahkan para konselor yang membantu persoalan kliennya yang berkaitan dengan peran jender atau masalah sosial budaya lainnya.

\section{PENUTUP}

Gender sebagai konstruksi sosial telah membedakan peran dan posisi perempuan dan laki-laki di dalam keluarga dan masyarakat. Pembedaan ini diturunkan secara kultural dan menjadi kepercayaan turun temurun dari satu generasi kegenerasi berikutnya serta diyakini sebagai idiologi, oleh sebab itu gender sebagai konstruksi sosial tidak abadi. Gender berubah dari waktu kewaktu, serta sangat dipengaruhi oleh politik, budaya, sosial dan ras.

Masalah perempuan dan gender adalah masalah yang timbul karena pandangan baku (stereotype) laki-laki dan perempuan dalam kaitan dengan peranan gender dan pembagian kerja gender.

Masalah gender timbul, apabila terdapat sikap diskriminatif yang menunjukkan suatu perlakuan yang berbeda terhadap laki-laki dan perempuan. Perlakuan berbeda ini didasarkan pada perbedaan jenis kelamin, umpamanya dalam masalah upah dan penggajian yang berbeda kepada pegawai laki-laki dan perempuan yang menduduki jabatan dan tugas yang sama. Contoh lain adalah perlakuan yang berbeda terhadap anak laki-laki dan perempuan dalam hal pendidikan, pengasuhan, kesempatan belajar, kesempatan kerja dan sebagainya.

Para konselor hendaknya memahami bahwa gender bisa menjadi masalah bisa juga tidak. Gender bisa menjadi masalah, jika: (1) perempuan tidak berkembang karena diharuskan di rumah saja, (2) Anak-anak perempuan tidak mendapat pendidikan seperti anak laki-laki karena dianggap tidak perlu, (3) Perempuan tergantung pada nafkah suami, sehingga apabila suaminya meninggal atau dicerai, perempuan tidak dapat menghidupi dirinya dan anak-anaknya karena tidak punya ketrampilan dan pengalaman yang mendukung, (4) Laki-laki tidak mau tahu dengan pekerjaan rumah tangga, karena merasa bukan tanggung jawabnya, meskipun istri sangat repot, (5) Laki-laki tidak mau memberikan hak kebebasan/ kesempatan bagi perempuan untuk ikut menentukan keputusan dalam rumah tangga, (6) Kebutuhan biologis mutlak dimonopoli lakilaki tanpa memperdulikan kepuasan istri.

Selanjutnya gender tidak menjadi masalah jika: (1) Terjadi kesepakatan antara kedua belah pihak (laki-laki dan perempuan) di dalam pembagian tugas, (2) Perempuan masih memiliki kesempatan untuk kegiatan lain di luar rumah untuk mengembangkan diri dan bermasyarakat dan (3) Laki-laki membantu perempuan dengan pekerjaan di rumah apabila tugas perempuan yang lain cukup berat.

Dengan perkembangan global yang terjadi sekarang ini, maka peran laki maupun perempuan cenderung mengalami perubahan dan perkembangan yang begitu pesat. Peranperan perempuan yang tadinya banyak berperan pada peran domestik, sekarang cenderung banyak mengarah pada peran-peran publik. Selain peran domestik yang merupakan warisan dari pendahulunya dan memang menjadi tugas utamanya di dalam membina keluarga. Kecenderungan perubahan peran perempuan tersebut terjadi karena adanya peluang yang semakin terbuka, dan tuntutan perubahan dan kesempatan yang sama dengan laki-laki, sehingga sektor publik yang semula didominasi laki-laki kini juga telah diisi oleh kaum perempuan.

Semoga dengan peluang ini, perempuan senantiasa mampu meningkatkan kualitasnya dalam segala bidang, sehingga kesetaraan dan keadilan gender dapat tercapai secara optimal.

\section{DAFTAR PUSTAKA}

Barbara freyer Stowasser, Woman in the Qur'an, Traditions, and interpretation, Oxford university Press, New York, 1994 
Derald Wing Sue \& David Sue, 2003. Counseling Culturally Diverse, Theory And Practice, John Wiley \& sons, INC,

Erich Fromm, Cinta, seksualitas, Matriarki, gender, Percetakan Jalasutra, Yogyakarta

John W. Berry. 1997. Handbook of CrossCultural Psyhology Volume 3 Social Behavir And Aplications, by allyn \& Bacon,

Lies Marcoes Natsir \& John Hendrik Meule- man, 1993. Wanita Islam Indonesia dalam kajian Tekstual dan Kontekstual, Hak cipta INIS,

Susan Golombok \& Robyn Fivush, 1994. Gender Development, Combridge University Press,

Ulfiah, Hubungan Antara Gaya Pengasuhan Orang Tua Yang Enabling Dan Constraining Dengan Eksplorasi Dan Komitmen Dalam Pencapaian Status Identitas peran Gender, Tesis, 2005 